e-Jurnal Ilmiah BIOSAINTROPIS (BIOSCIENCE-TROPIC)

Volume 6/ No.: 1 / Halaman 72 - 81 / Agustus Tahun 2020

ISSN: 2460-9455 (e) - 2338-2805(p)

\title{
Kondisi Lingkungan dan Persepsi Masyarakat Perairan Tambak Garam di Dusun Ageng Desa Pinggir Papas, Sumenep Madura
}

\section{Environmental Conditions and Perceptions of Salt Pond Community in Ageng Hamlet, Pinggir Papas Village, Sumenep Madura}

\author{
Rohmi Romdana $^{1 *}$, Ahmad Syauqi $^{2 * *}$, Husain Latuconsina ${ }^{3}$ \\ ${ }^{123}$ Jurusan Biologi Fakultas Matematika dan ilmu Pengetahuan Alam Universitas Islam Malang, Indonesia
}

\begin{abstract}
ABSTRAK
Garam meupakan salah satu produk komodatis yang strategis bagi kehidupan manusia saat ini, tidak hanya digunakan sebagi konsumsi, garam saat ini sudah banyak di gunakan sebagai bahan untuk industri, produk kecantikan, pertanian dan kesehatan. Penentu kualitas garam tergantung dari kondisi perairan dan kondisi lingkungan sekitar yang di jadikan sebagai tempat produksi garam. Tujuan penelitain ini yaitu untuk mengetahui kondisi awal perairan tambak garam dan persepsi masyarakat tentang kondisi lingkungan di dusun Ageng desa Pinggir Papas, Sumenep Madura. Metode yang diguankan pada penelitain yaitu metode deskriptif kuantitatif ekploratif dan teknik pengumpulan data pada penelitian ini menggunakan purposive sampling. Pengambilan data dilakukan pada 3 stasiun (Kolam) dengan ulangan Duplo. Hasil rata-rata pengukuran kondisi awal perairan tambak garam di dusun Ageng diperoleh suhu antara 31-34 ${ }^{\circ} \mathrm{C}$, kekeruhan 5,80-7,91 NTU, Konduktivitas 1985-1988 $\mu \mathrm{S} / \mathrm{cm}, \mathrm{pH}$ 7,2-7,5, COD 20,45-26,23 mg/L, plastic 2-4 partikel, coliform 15-150/100 ml dan untuk nilai persepsi didapati nilai yang tinggi. Kondisi perairan dan lingkungan tambak garam di dusun Ageng menunjukan kondisi yang tergolong batas normal hingga tercemar ringan untuk bahan baku produksi garam.
\end{abstract}

Kata Kunci: produksi garam, kondisi perairan dan persepsi masyarakat

\section{ABSTRACT}

Salt is one of the strategic commodity products for human life today, not only used as consumption, salt is now widely used as material for industry, beauty products, agriculture and health. Determination of salt quality depends on the condition of the waters and environmental conditions that are made as a place of salt production. The purpose of this research is to determine the initial conditions of salt pond waters and community perceptions about the environmental conditions in Ageng hamlet of Pinggir Papas village, Sumenep Madura. The method used explorative quantitative descriptive and data collection techniques in this study using purposive sampling. Data retrieval is done at 3 stations (pond) with duplo tests. The results of the measurement of the average initial conditions of salt pond waters in the village of Ageng obtained temperatures between 31-34 ${ }^{\circ} \mathrm{C}$, turbidity of 5.80$7.91 \mathrm{NTU}$, conductivity 1985-1988 $\mathrm{\mu S} / \mathrm{cm}, \mathrm{pH}$ 7.2-7.5, COD 20.45-26.23 mg / L, 2-4 plastic particles, coliform 15-150/100 $\mathrm{ml}$ and for the value of perception found high values. The condition of the waters and the environment of salt ponds in the Ageng hamlet shows conditions that are classified as normal limits to mild contamination for raw materials for salt production.

Keywords: salt production, water conditions and community perception

*) Rohmi Romdana, Jurusan Biologi FMIPA UNISMA, Jl. Mt. Haryono193, Malang 65144, 087861747652 and E-mail: rohmiromdana@gmail.com

**) Ir. Ahmad Syauqi, M.Si, Jurusan Biologi FMIPA UNISMA, J1. Mt. Haryono 193, Malang 65144, 08986307836 and email: syauqi.fmipa@unisma.ac.id

Diterima Tanggal 5 Agustus 2020 - Dipublikasikan Tanggal 25 Agustus 2020 
e-Jurnal Ilmiah BIOSAINTROPIS (BIOSCIENCE-TROPIC)

Volume 6/ No.: 1 / Halaman 72 - 81 / Agustus Tahun 2020

ISSN: 2460-9455 (e) - 2338-2805(p)

\section{Pendahuluan}

Garam merupakan salah satu komoditas strategis, selain sebagai kebutuhan dapur garam juga merupakan bahan baku industri. Garam sangat berperan penting dalam beberapa aspek kehidupan manusia, seperti halnya penggunaan garam banyak dilibatkan pada industry kimia, kecantikan, pertanian dan perternakan serta industri lainnya. Oleh sebab itu garam tidak bisa di jauhkan dari aktivitas manusia serta keadaan garam pun perlu diperhatikan kualitasnya.

Salah satu faktor penentu kualitas garam dapat ditentukan dengan kondisi lingkungan perairan yang dijadikan bahan baku pembuat garam serta kondisi sekitar tempat pembuatan garam. Kondisi lingkungan merupakan keadaan suatu lingkungan yang di ukur dari kombinasi faktor fisik, kimia dan biologi suatu lingkungan. Kondisi lingkungan merupakan gambaran keberadaan suatu lokasi yang menjelaskan keadaan yang dialami oleh lingkungn tersebut

Kabupaten Sumenep memiliki letak geografis yang terdiri dari daratan dan kepulauwan, bagian daratan memiliki luas 1.146,93 $\mathrm{Km}^{2}$ [1]. Desa Pinggi-Papas secara administrasi merupakan salah satu desa bagian dari kecamatan Kalianget Kabupaten Sumenep yang terletang di pesisir Kabupaten Sumenep. Desa Pinggir Papas merupankan salah satu desa yang terkenal dengan aktifitas petani garam pertama di Kabupaten Sumenep, yang sudah tertulis dalam sejarah asal muasal pembuatan garam di Madura.

Paradigma sebagian masyarakat pesisir yang menganggap laut sebagai tempat pembuangan sampah [2]. Pesisir yang memiliki fungi sebagai tempat penampungan limbah juga memilik kapasitas tampung yang tergantung dari volume dan jenis limbah yang masuk, selain sebagai pemanpungan limbah, pesisir juga memiliki fungsi sebagi penyedia jasa pendukung untuk aktivitas kehidupan manusia. Apabila daya tampung limbah tidak seimbang dengan kondisi pesisir maka akan terjadi kerusakan fungsi terhadap penyediaan jasa pendukung aktivitas kehidupan manusia atau dengan kata lain pesisir akan mengalami pencemaran [3]. Hal ini jika terjadi tentunya berpotensi penurunan kualitas perairan untuk produksi garam. Jika hal ini dibiarkan terus menurus akan berdampak pada kualitas garam serta akan berdampak buruk terhadap masyarakat yang memiliki kebiasaan mengkonsumsi garam secara langsung setelah proses pemanenan. Tambak garam yang terkontaminasi oleh sampah menyebabkan hasil produksi garam tradisional semakin lama semakin menguning yang diduga efek dari pencemaran sampah [4]. Ancaman dari menumpuknya sampah di pesisir akan menyebabkan garam terkontaminasi dengan mikroplastik.

Persepsi masyarakat merupakan salah satu aspek sikologi pada manusia untuk merespon berbagai aspek dan gejala yang terjadi di sekitarnya [5], persepsi merupakan respon dan tanggapan dari manusia terhadap kondisi dan kejadiaan yang terjadi di sekitar. Dalam penelitian ini persepsi masyarakat tentang kondisi lingkungan dan perairan tambak garam dilihat apakah memiliki kesamaan hasil antara kondisi perairan tambak garam dengan persepsi masyarakat terhadap kondisi lingkungan perairan tambak garam di dusun ageng desa pinggir papas

Berdasarkan latar belakang ini, maka peneliti bertujuan mempelajjari kondisi lingkungan perairan tambak garam serta persepsi masyarakat terhadap keadaan lingkungan pesisir di kawasan produksi garam tradisional di Dusun Ageng Desa Pinggir Papas Kabupaten Sumenep menjadi hal yang penting untuk dilakukan, sebagai bahan informasi untuk pengelolaan lingkungan dan produksi garam tradisonal yang bermutu dan terbebas dari bahan kontaminan.

\section{Material dan Metode}

\section{Bahan dan Alat}

Bahan yang digunakan dalam penelitian ini adalah sampel perairan tambak, $\mathrm{K}_{2} \mathrm{Cr}_{2} \mathrm{O}_{7}, \mathrm{AgSO}_{4}$, $\mathrm{HgSO}_{4}$, Pottasium hidroftalat $\left(\mathrm{C}_{8} \mathrm{H}_{5} \mathrm{KO}_{4}\right), \mathrm{H}_{2} \mathrm{SO}_{4}$, Alkohol, Aquades, serbuk Lauryl Triptose Broth, Tissue, alat tulis, $\mathrm{KOH} \mathrm{10 \% ,} \mathrm{Kertas} \mathrm{Sampul.} \mathrm{Alat} \mathrm{digunakan} \mathrm{dalam} \mathrm{penelitian} \mathrm{ini} \mathrm{meliputi:} \mathrm{pH}$ meter, konduktivity-meter, Termometer, pipet tetes, gelas beker, botol sampel, Turbidimeter, spektrofotometer UV-Vis, Erlenmeyer, Corong, labu ukur, Kamera, Plankton net berukuran $30 \mu \mathrm{m}$, Tabung reaksi, Tabung Durham, Cawan. 
e-Jurnal Ilmiah BIOSAINTROPIS (BIOSCIENCE-TROPIC)

Volume 6/ No.: 1 / Halaman 72 - 81 / Agustus Tahun 2020

ISSN: 2460-9455 (e) - 2338-2805(p)

\section{Metode}

Metode penelitian yang digunakan yaitu metode survey dengan deskriptif kuantitatif ekploratif, yaitu pengamatan secara langsung pada tempat penelitian [6]. Kualitas perairan yang diukur meliputi parameter Fisik, Kimia dan Biologi yang dilakuna secara insitu dan eksitu. pengamatan insitu langsung dilakukan di tempat pengamatan sedang pengamatan eksitu dilakuakan di Laboratorium terkait. Analsisi data yang digunakan pada penelitian ini yaitu analisis kuantitatif dengan menggunakan aplikasi exel. Penelitian ini dilakuakn pada 3 stasiun dengan 2 kali pengulangan (Duplo).

Persepsi masyarakat meliputi responden dari warga RT 08 dusun Ageng yang dekat dengan tambak garam diambil secara purposive sampling, dengan memberikan angket terhadap responden tengtang persepsi masyarakat terhadap kondisi lingkungan dan kualitasperairan tambak garam di dusun Ageng.

Tabel 1. Skala Nilai Rata-Rata (Interval) Persepsi Masyarakat

\begin{tabular}{|c|c|}
\hline Skala & Kategori \\
\hline $3,26-4,00$ & Sangat Tinggi \\
\hline $2,49-3,25$ & Tinggi \\
\hline $1,76-2,50$ & Sedang \\
\hline $1,00-1,75$ & Renda \\
\hline
\end{tabular}

Sumber: [7]

\section{Cara Kerja}

Penelitian ini dimulai dari penyebaran angket pada masyarakat yang tinggal didekat perairan tambak garam. Penyebaran angket dilkukan secara langsung kepada mayarakat, pengisian angket berada dalam pemantauan peneliti untuk memastikan keakuratan data. Pertama melakukan pengamatan ovservasi langsung, penyebaran angket dan pengambilan data wawancara.

Pengukuran kualitas perairan tambak garam dimulai dari penentuan stasiun, pengambilan sampel dan pengukuran kondisi perairan tambak garam.

Pengambilan sampel: Pengambilan sampel dilkuakan pada tanggal 18 juni - 19 juni untuk diteliti. Sampel diambil langsung menggunakan botol sampel, untuk menjaga kondisi sampel tetap dalam kondisi sama dilakukan penyimpanan sample menggunkaan Coolbox. Pengambilan sampel plastik dengan menggunakan plankton net (diameter $25 \mathrm{~cm}$ dan mesh size $30 \mu \mathrm{m}$ ). Plankton net ditempatkan di permukaan perairan selama 5 menit dengan berlawanan arah arus. Kemudian sampel air yang telah diambil tersebut kemudian dimasukkan ke dalam botol sampel

Pengukuran: Pengamatan sampel dilakukan secara langsung di tempat pengambilan sampel dan penelitian lab. Pengamatan langsung meliputi pengukuran suhu dan $\mathrm{pH}$. Untuk penelitian lab meliputi pengukuran COD, Kekeruhan, Konduktivitas, Coliform dan plastik. Penelitian dilakukan sebanyak dua kali ulangan dengan menggunakan jenis pengulangan Duplo per stasiun. Termometer dimasukkan pada sampel air, ditunngu hingga tanda merah berhenti bergerak dengan tidak menyentuh bagian kaca agar tidak mengganggu keakuratan suhu. Kekeruhan, terlebih dahulu di lakukan kalibrasi hinnga angka menunjukkan 0,00 NTU, sampel di masukkan pada botol suspensi dan dimasukkan pada bagian kerja alat hingga nilai kekeruhan berhenti menunjukkan nilai kekeruhan sampel yang diamati. Konduktivitas: alat di kalibrasi menggunkan $\mathrm{KCl} 0,01 \mathrm{M}$, elektroda di masukkan pada sampel tunggu hingga digit berhenti dan menunjukan angka konduktivita larutan. $\mathrm{pH}$ : $\mathrm{pH}$ meter di netralkan terlebih dahulu dengan akuades, $\mathrm{pH}$ meter di letakkan pada sampel hingga angka digit berhenti, di catat nlai $\mathrm{pH}$.

Analisis COD: kalibrasi pengukuran ini digunakan Kalium hidroftalat sebagai standarisasi, $\mathrm{K}_{2} \mathrm{Cr}_{2} \mathrm{O}_{7}+\mathrm{HgSO}_{4} 0,02 \mathrm{M}$ sebanyak 1,5 ml, $\mathrm{H}_{2} \mathrm{SO}_{4}+\mathrm{Ag}_{2} \mathrm{SO}_{4}$ sebanyak 3,5 $\mathrm{ml}$ dalam tabung bulusilikat, di tambahkan $2,5 \mathrm{ml}$ sampel kemudian di panaskan dengan suhu $150^{\circ} \mathrm{C}$ selama 2 jam dan di dinginkan dengan suhu ruang, diamati dengan spektofotometri dengan panjang gelombang $420 \mathrm{~nm}$ [8]. Analisa Mikroplastik: sampel yang di saring dengan menggunkan plankton net ditambahkan $\mathrm{KOH} 10 \%$ untuk 
e-Jurnal Ilmiah BIOSAINTROPIS (BIOSCIENCE-TROPIC)

Volume 6/ No.: 1 / Halaman 72 - 81 / Agustus Tahun 2020

ISSN: 2460-9455 (e) - 2338-2805(p)

menghilangn bahan organic yang di tidak diingin kan selama 24 jam dengan suhu kamar, di saring menggunakan kertas Whatmen dan diamati di bawah mikroskop stereo [9].

Analisa Coliform dan E coli: Metode penentuan NPM tabung seri 9 untuk deteksi keberadaan coliform di gunakan media ekstrak daging sapi, pepton, laktosa dengan perbandingan 1:1:1; diganti dengan medium Lauryl Triptose Broth, ditambahkan $9 \mathrm{ml}$ media ke dalam tabung reaksi yang sudah di beri tabung durham dengan kondisi steril, dengan sampel 0,1 ml, $1 \mathrm{ml}$, dan $10 \mathrm{ml}$. Di inkubasi selama 24 jam dengan suhu $35-36^{\circ} \mathrm{C}$, diamati gelumbung gas pada tabung reaksi, di catat dan dan dihitung menurut tabel MPN, penegasan dengan medium petrifilm [10] dilakukan pengenceran $10^{-3}$ sebelum inokulasi dan di inkubasi selama 24 jam ddengan suhu $35-36^{\circ} \mathrm{C}$, koloni di amati di bawah cahaya.

\section{Hasil dan Diskusi}

Hasil pengukuran kondisi lingkungan perairan tambak garam di dusun Ageng desa Pinggir Papas ditunjukkan pada Tabel 2.

Tabel 2. Hasil Pengukuran Kualitas Air di Dusun Ageng Desa Pinggir

\begin{tabular}{|c|c|c|c|c|c|}
\hline \multirow[t]{2}{*}{ Parameter } & \multirow[t]{2}{*}{ Satuan } & \multirow[t]{2}{*}{ Baku Mutu* } & \multicolumn{3}{|c|}{ Rata-Rata Hasil pengukuran } \\
\hline & & & $\mathrm{A}$ & $\mathrm{B}$ & $\mathrm{C}$ \\
\hline \multicolumn{6}{|l|}{ Fisika } \\
\hline Suhu & ${ }^{\circ} \mathrm{C}$ & $28-30^{\circ} \mathrm{C}$ & 33 & 32 & 33,5 \\
\hline Kekkeruhan & NTU & $<5$ & 6,13 & 7,51 & 7,56 \\
\hline Konduktivitas & $\mu \mathrm{S} / \mathrm{cm}$ & - & 1987 & 1986 & 1986 \\
\hline \multicolumn{6}{|l|}{ Kimia } \\
\hline $\mathrm{pH}$ & - & $7-8,5$ & 7,3 & 7,3 & 7,5 \\
\hline COD & $\mathrm{mg} / \mathrm{L}$ & - & 25,82 & 22,7 & 20,32 \\
\hline Plastik & Potongan kecil & - & 4 & 4 & 2 \\
\hline Biologi & & & & & \\
\hline Coliform, & $\mathrm{MPN} / 100 \mathrm{ml}$ & $1000 / 100 \mathrm{ml}$ & 27 & 38 & 120 \\
\hline$E \operatorname{coli}^{* *}$ & $\mathrm{MPN} / 100 \mathrm{ml}$ & - & - & $49 * * *$ & - \\
\hline
\end{tabular}

*Kepmen LH no.51 Tahun 2004 [24]

** Pengamatan Penegasan dengan petrifilm

*** ditumbuhkan pada suhu $35-36{ }^{\circ} \mathrm{C}$

Kondisi Abiotik Perairan Tambak Garam: Hasil rata-rata pengukuran suhu pada perairan tambak garam dusun Ageng memiliki nilai rata-rata sebesar Hasil rata-rata pengukuran suhu pada perairan tambak garam dusun Ageng memiliki nilai rata-rata sebesar $33^{\circ} \mathrm{C}$ pada stasiun $\mathrm{A}, 32^{\circ} \mathrm{C}$ pada stasiun $\mathrm{B}$ dan $33,5^{\circ} \mathrm{C}$ pada stasiun $\mathrm{C}$, kondisi ini masih terbilang normal pada perairan tambak garam, atas kisaran Optimal suhu air laut di indonesia yaitu $28-32{ }^{\circ} \mathrm{C}$ [11]. Dari hasil pengukuran suhu yang paling tinggi dan melebihi batas baku mutu suhu air laut menurut Kepmen LH No.51 tahun 2004, di peroleh nilai sebesar $34{ }^{\circ} \mathrm{C}$ yaitu pada hasil pengukuran stasiun A dan stasiun $\mathrm{C}$ dengan ulangan pertama. pengukuran suhu air tambak garam berkisar $28-33{ }^{\circ} \mathrm{C}$ [12]. Suhu normal yang terjadi di diperairan indonesi utnuk biota laut tropis berkisar $27-32^{\circ} \mathrm{C}$. Dari hasil pengukuran suhu pada perairan tambak garam dusun Ageng bisa dikatakan normal untuk suhu perairan tambak garam. Kondisi lingkungan di dusun Ageng juga mendukung tingginya suhu perairan yang di akibatkan dari kurangnya penghijauan di dusun Ageng (Sedikit tumbuhan di sekitar) dan banyaknya uapan dari produksi garam pada saat pengkristalan garam, kondisi inilah yang juga mendukung suhu panas (tinggi) pada perairan di dusun Ageng. 
e-Jurnal Ilmiah BIOSAINTROPIS (BIOSCIENCE-TROPIC)

Volume 6/ No.: 1 / Halaman 72 - 81 / Agustus Tahun 2020

ISSN: 2460-9455 (e) - 2338-2805(p)

Pengukuran kekeruhan pada perairan tambak garam di dusun Ageng Desa Pinggir-Papas yaitu sebesar 6,82 NTU pada stasiun A, 7,51 NTU pada stasiun B dan 7,56 NTU pada stasiun C, kondisi kekeruhan dari semua tasiun ini melebihi batas baku mutu kekruhan air laut menurut Kepmen LH No. 51 tahun 2004 yaitu $>5$ NTU, Nilai kekeruhan tertinggi terjadi pada stasiun C ulangan ke-2 yaitu sebesar 7,91 NTU dan stasiun B ulangan pertama. Kondisi ini sama halnya dengan hasil penelitian Putra, tentang kondisi air laut kuta akibat cemaran sampah di pesisir pantai bali menyebutkan hasil pengukuran kekeruhan yang melebihi baku mutu kualitas air laut yaitu berkisar 0,30-18,70 NTU [13]. Factor yang mempengaruhi kekeruhan juga bisa akibatkan dari Curah hujan, run-off sampah dari daratan lewat sungai-sungai dan kuat arus yang dapat menyebabkan substrat teraduk [11], dari pernyataan ini kondisi yang sering terjadi pada perairan tambak garam di dusun Ageng yaitu run-off sampah dari masyarakat sekitar perairan tambak garam dan Dari hasil data persepsi tentang kondisi perairan memiliki hubungan dengan kondisi kekeruhan pada perairan, dimana persepsi ini memiliki nilai sedang atau perairan masih dikategorikan kotor akibat sampah rumah tangga yang dibuang ke sungai.

Pengukuran konduktivitas perairan tambak garam Dusun Ageng desa Pinggir-Papas yaitu 1987 $\mu \mathrm{S} / \mathrm{cm}$ pada stasiun A, $1985 \mu \mathrm{S} / \mathrm{cm}$ pada staiun B dan $1986 \mu \mathrm{S} / \mathrm{cm}$ pada stasiun C. untuk baku mutu nilai konduktivitas air laut tidak memiliki baku mutu, nilai konduktivitas suatu perairan menunjukkan konsentrasi ion total yang terkandnung. Kondisi pengukuran konduktivitas pada perairan tambak garam di dusun Ageng menunjukkan nilai yang tinggi, menurut Irwan, air laut memiliki nilai konduktivitas yang terbilang tinggi dikarenkan kandungan garam yang terlarut tinggi [14], sehingga ion di dalamnya juga bernilai tinggi. Dari hasli penelitain Khairunnas, nilai konduktivitas pada air laut berkisar mulai dari 1.874,5 - 13.075,5 $\mu \mathrm{S} / \mathrm{cm}$. Kondisi perairan tambak garam di dusun Ageng merupakan perairan yang dialirkan langsung dari air laut dan dialirkan dari satu sungai ke sungai lain untuk mendapatkan konsentrasi kadar garam yang tinggi.

Pengukuran $\mathrm{pH}$ pada perairan tambak garam di Dusun Ageng Desa Pinggir Papas yaitu 7,3 pada stasiun A, 7,3 pada stasiun B dan 7,5 pada stasiun $\mathrm{C}$, konidisi ini terbilang kondsi normal, kondisi $\mathrm{pH}$ air laut yang baik berada pada kondisi basa yaitu pH>7 [11]. Kepmen LH No. 512004 menetapkan kondisi $\mathrm{pH}$ pada air laut berkisar dari 7-8,5. Dari ketiga stasiun sudah masuk dalam kondisi normal untuk air laut akan tetapi kondisi ini cenderung sedikit asam untu ukuran air laut pada produksi garam. Kondisi pH pada perairan Tambak Garam dari hasil penelitian Fitriyah [12], nilai pH pada perairan tambak garam di desa Kedung Mutih diperoleh nilai 8-9. Dari perbandingan ini kondsi pH di perairan tambak Garam dusun Ageng memiliki nilai $\mathrm{pH}$ yang sedikit cenderung lebih asam untuk ukuran air laut untuk produksi garam. Nilai $\mathrm{pH}$ suatu perairan menggambarkan kondisi perbandingan unsur kimia di dalamnya , umumnya kondsi $\mathrm{pH}$ di perairan lebih mendekati kearah Basa. Hal ini erat kaitnya dengan keberadaan sampah organik yang di buang pada perairan, nilai $\mathrm{pH}$ dapat dipengaruhi oleh limbah industry, Limbah rumah tangga dan laju fotosintesa [15].

Pengukuran COD pada perairan tambak Garam di Dusun Ageng desa Pinggir-Papas yaitu 25,82 $\mathrm{mg} / \mathrm{L}$ pada staiun A, $22,7 \mathrm{mg} / \mathrm{L}$ pada stasiun B dan $20,32 \mathrm{mg} / \mathrm{L}$ pada stasiun C, kondisi ini masih berada paad batas aman cod air tambak. kondisi COD perairan tambak yang ideal yaitu $<25 \mathrm{mg} / \mathrm{L}$ [16].

Hasil pengukuran dari ke-3 stasiun mengalami penurun dalam urutan stasiun hal ini bisa di sebakan dari keadaan bahan organic maupun bahan anorganik yang dikandung dalam perairan, tingginya nilai COD suatu perairan di akibatkan dari keberadaan bahan organi maupun anorgani dari limbah yang di hasilkan [17], hal ini berbanding terbalik dari hasil pengukuran COD di perairan tambak Garam, nilai COD yang tinggi barada pada hasil pengukuran Stasiun A yang memiliki lokasi jauh dari pemukiman yang di duga memiliki hasil nilai COD yang lebih renda yang dilihat dari keberadaan dan lokai staiun, stasiun yang lebih dekat dengan Bungan limbah dan pemikiman di duga memiliki nilai COD yang lebih tinggi, penurunan nilai COD di akibatkan dari penurunan bahan organic maupun bahan anorganik dan tingkat kejernian air [8], hal ini selaras dengan hasil pengkuran kekruhan yaitu pada stasiun A memiliki nilai kekeruhan 5,8-6,5 NTU akan tetapi dimana kondisi COPD pada stasiun A lebih mendekati kondisi ideal.

Hasil pengamatan mikropastik pada perairan tambak garam dusun Ageng desa Pinggir-Papas yaitu di hasilkan kelimphan yang tebilang sedikit yaitu 2-4 potongan kecil dengan ukuran 0,1-2,00 mm, pada stasiun A di peroleh 4 potongan kecil dengan 2 jenis mikroplastik yaitu 3 Fiber dan $1 \mathrm{r}$ fragmen, stasiun 
B di peroleh hasil 4 potongan kecil dengan jenis yang sam pada stasiun A yaitu 3 Fiber dan 1 Fragmen dan yang terakhir yaitu pada stasiun $\mathrm{C}$ di hasilkan 2 potongan kecil dengan jenis Fiber hal yeng mempengaruhi distribusi mikroplasti yaitu kecepatan arus dan laju angina [18]. Kecilnya kelimpahan mikroplastik yang terjadi pada perairan tambak garam di Dusun ageng desa Pinggir-Papas bisa diakibatkan dari kekuatan arus perairan yang berkekuatan kecil serta cara pengaliran perairan yang banyak banyak melewati sungai-sungai atau dengan kata lain terfilter dari sungai- sungai sebelum memasuki sungai yang dijadikan stasiun pengamatan serta periran tambak garam di dusun Ageng sudah melewati proses pemompaand dari laut. Perbandingan penelitian dari Tahir mikroplastic banyak di temukan pada pada tambak garam tradisional di Makasar, mikroplastik pada air lebih sedikit terdeteksi dari pada mikroplatik pada garam dan sedimen di tambak garam Makasar. Keberadaan penyebaran mikroplastik di perairan tergantung dari jenis densita platik itu sendiri. Dan umumnya platik yang memiliki densitas renda berada pada permukaan[19].

Kondisi Biotik: Nilai NPM pada perairan tambak garam dusun Ageng terbilang kecil dari baku mutu yang di tetapkan oleh Kepmen LH No. 51 tahun 2004 yaitu 1000/100ml, kecilnya kepadatan bakteri Coliform di wilayah pesisir diakibatkan dari sedikitnya limbah fekal yang masuk [20] ke perairan melewati kolam-kolam. Tabel 3 menunjukkan Nilai MPN dari stasiun A sebesar 0,15 atau 15/100ml pada ulangan pertama dan 0,38 atau $38 / 100 \mathrm{ml}$, stasiun B memiliki nilai MPN sebesar 0,38 atau 38/100ml dari kkedua ulangan dan stasiun C memiliki nilai MPN sebesar 0,90 atau 90/100ml pada ulangan pertama dan 1,50 atau 150/100ml pada ulangan ke-2. Dari hasil persepsi masyarakan juga benyebutkan bahwa perairan tambak di dusun Ageng desa Pinggir Papas itu dekat dengan pencemaran (limbah rumah tangga) dan masyarakat juga menyebutkan bahwa kondisi perairan tambak garam di dusun Ageng terbilang kotor akibat pembuangan limbah rumah tangga pada pereairan tersebut.

Tabel 3 Hasil Perhitungan MPN dan Uji Pendugaan Coliform dan E coli

\begin{tabular}{|c|c|c|c|}
\hline \multirow{2}{*}{ Sampel } & $\begin{array}{c}\text { MPN } \\
\text { per100ml }\end{array}$ & $\begin{array}{c}\text { Jumla Koloni } \\
\text { Coliform pada } \\
\text { Petrifilm (Sel) per } \\
11,1 \mathrm{ml}\end{array}$ & $\begin{array}{c}\text { Jumlah E coli } \\
\text { pada Petrifilm } \\
\left(35^{\circ} \mathrm{C}\right)\end{array}$ \\
\hline \multirow{2}{*}{ Stasiun A } & 15 & TBUD & - \\
\cline { 2 - 4 } & 38 & $1,98.10^{5}$ & - \\
\hline \multirow{2}{*}{ Stasiun B } & 38 & TBUD & $4,9.10^{4}$ \\
\cline { 2 - 4 } & 38 & $2,38.10^{5}$ & - \\
\hline \multirow{2}{*}{ Stasiun C } & 90 & $1,45.10^{5}$ & - \\
\cline { 2 - 4 } & 150 & TBUD & - \\
\hline
\end{tabular}

Uji penegasan pada penelitian ini menggunkan metode media padat yaitu Petrifil 3M, dari hasil pengmatan petrifilm pada semua stasiun memiliki hasil deteksi adanya bakteri Coliform yang ditunjukkan dengan adanya koloni berwarna merah [21], dan digunakan pengenceran ke-3 untuk perhitungan kolini bajteri Coliform. Pada stasiun A1 di peroleh koloni berwarna merah sebanyak lebih dari 250 atau bisa di sebut TBUD (too numerous to cont) dan pada A2 diperoleh koloni berwarna merah sebnayk 198 koloni, stasinu B1 didapati adanya koloni bebanyak TBUD dan B2 diperoleh 238 koloni berwarna mera dan 49 koloni berwarna biru (E.coli), stasiun C di peroleh koloni sebanyak 145 pada C1 dan TBUD pada C2.

Keberadaan $E$ coli yang hanya terdeteksi pada stasiun B menggambarkan bahwa kondisi bahan organic di situ lebih tinggi, utamnya diduga akibat dari dekatnya keberadaan kandang hewan ternak masyarakat yang tinjanya langsung di buang padaperairan. Keberadaan E coli merupakan bakteri yang berasal dari kotoran manusia dan hewan [22]. Dari hasil persepsi masyarakan juga benyebutkan bahwa 
perairan tambak di dusun Ageng desa pinggir papas itu dekat dengan pencemaran yang pada stasiun $\mathrm{B}$ selain limbah rumah Tangga juga limbah kotoran hewan ternak.

Persepsi Masnyarakat: Hasil persepsi masyatrakta tentang kondisi lingkungan perairan tambak garam di dusun Ageng dapat dikategorikan dengan nilai sangat tinggi yaitu dengan pemahman lingkungan yang tinggi atau setuju akan tetapi hasil survey menunjukkan nilai kondisi lingkungan yang negative. Pernyataan kondisi kebersihan lingkungan di dusun ageng masyarakat memberikan nilai ratarata kurang setuju, dengan nilai sangant setuju sebanyak $12 \%$, setuju $22 \%$ dan kurang setuju $66 \%$, Pernyataan " masyarakat dusun Ageng sudah bias menerapkan lingkungan bersih dan san sehat" dengan rata-rata nilai tinggi, sebanyak $12 \%$ sangat setuju, $28 \%$ setuju. Pernyataan mengenai pemahaman masyarakat tentak konsep lingkungan bersih rata masuk dalam kategori sangat setuju, seperti pernyataan "kebersihan lingkungan adalah tidak membuang sampah sembarangan" sebanyak $67 \%$ sangat setuju, 29\% setuju dan 4\% kurang setuju. Pernyataan "menjaga kebersihan dan kesehatan lingkungan sangat penting" sebanyak $74 \%$ sangat setuju dan $26 \%$ setuju. Pernyataan "hidup sehat berawal dari lingkungan yang sehat dan bersih" sebanyak $78 \%$ sangat setuju dan $22 \%$ setuju. Dari persepsi ini sudah dapat dilihat bahwa masyarakat mengerti dan paham tentang lingkungan bersih dan sehat akan tetapi dalam prakteknya masyarakat di dusun Ageng masih blom bias menerapkan lingkungan bersih dan sehat.

Tabel 4. Hasil Skala Nilai Rata-Rata Persepsi Masyarakat

\begin{tabular}{|l|c|c|}
\hline \multicolumn{1}{|c|}{ Teks Pernyataan } & Nilai & Kategori \\
\hline $\begin{array}{l}\text { Kebersihan lingkungan adalah tidak membunag sampah di } \\
\text { sekitar rumah. }\end{array}$ & 3,7 & Sangat Tinggi \\
\hline Menjaga kebersihan dan kesehatan lingkungan sangat penting & 3,74 & Sangat Tinggi \\
\hline $\begin{array}{l}\text { Kondisi lingkungan di Dusun Ageng Desa pinggir papas } \\
\text { sudah tergolong lingkungan bersih. }\end{array}$ & 2,1 & Sedang \\
\hline $\begin{array}{l}\text { Masyarakat dusun ageng sudah bisa menerapkan lingkungan } \\
\text { bersih dan sehat }\end{array}$ & 2,5 & Tinggi \\
\hline Hidup sehat berawal dari lingkungan yang sehat dan bersih & 3,8 & Sangat Tinggi \\
\hline $\begin{array}{l}\text { pengelolahan sampah di Desa Pinggir papas sudah tergolong } \\
\text { baik }\end{array}$ & 2 & Sedang \\
\hline Perlu di sediakan TPS & 3,62 & Sangat Tinggi \\
\hline $\begin{array}{l}\text { Membuang sampah sembarang kesungai merupakan perilaku } \\
\text { yang tidak baik }\end{array}$ & 3,56 & Sangat Tinggi \\
\hline $\begin{array}{l}\text { Pemindahan sampah ke tempat penampungan sementara } \\
\text { penting dilakukan secara rutin }\end{array}$ & 3,4 & Sangat Tinggi \\
\hline $\begin{array}{l}\text { Pembayaran biaya restribusi untuk fasilitas peneglolahan } \\
\text { sampah perlu dilakukan }\end{array}$ & 3,24 & Tinggi \\
\hline $\begin{array}{l}\text { Kondisi perairan tambak garam di dusun ageng sudah } \\
\text { tergolong bersih }\end{array}$ & 2,44 & Sedang \\
\hline $\begin{array}{l}\text { Pengelolahan perairan tambak garam dusun ageng sudah } \\
\text { berjalan dengan baik }\end{array}$ & 2,62 & Tinggi \\
\hline Perairan tambak garam di dusun ageng jauh dari pencemaran & 2,42 & Sedang \\
\hline Kondisi perairan yang keruh termasuk parairan yang tercemar & 3,22 & Tinggi \\
\hline Sungai bukan tempat pembuangan sampah & 3,74 & Sangat Tinggi \\
\hline
\end{tabular}


e-Jurnal Ilmiah BIOSAINTROPIS (BIOSCIENCE-TROPIC)

Volume 6/ No.: 1 / Halaman 72 - 81 / Agustus Tahun 2020

ISSN: 2460-9455 (e) - 2338-2805(p)

Persepsi tentang pengelolah sampah di dusun ageng dikategorikan kuarang baik dalam pengelolahan sampah. Dari penyataan " pengelolahan sampah di dusun ageng sudah tergolong baik" sebanyak $20 \%$ sangat setuju, $20 \%$ setuju dan $60 \%$ kurag setuju, hal ini berhubungan dengan pentyedian TPS yang masih blom tersedia lengkap di dusun Ageng, pernyataan tentang penyediaan TPS masyarakan berpendapat perlu di sedikan TPS di dusun Ageng diaman sebanyak $62 \%$ sangat setuju dan $38 \%$ setuju untuk diberikan fasilitas TPS yang lengkap di desa pinggir papas dan di dukung jugu dengan pernyataan diadaakan biaya distribusi untuk pengeloahan sampah yang rata-rata masyarakat sangat setuju akan pernyataan ini. Persepsi masyarakat tentang konsep pengelolahan sampah yang baik denag niali rata-rata masyarakat sangat setuju, pernyataan " membuang sampah ke sungai merupakan perilaku tidak baik" sebanyak 56\% sangat setuju dan $44 \%$ setuju, pernyataan "pemindaan sampah ke tempat penampungan sementara penting dilakukan secara rutin" sebanyak $40 \%$ sangat setuju dan $60 \%$ setuju. Dari hail persepsi ini sudah dapat dilihat pengelolahan samapah di dusun ageng kurang baik dengan persepsi pemahaman pengelolhan yang baik. Dari hasil penelitian Desahariyanto, memaparkan kondisi pengelolahan sampah di desa pinggir papas tergolong pada kuadran 4 atau rendah [23].

Persepsi masyarakat dusun Ageng terhadap kondisi perairan tambak garam di dusun ageng tergolong kurang bersih, dengan sebanyak $8 \%$ sangat setuju, 52\% setuju dan $40 \%$ kurang setuju, jika dilihat dari pengukuran kondisi lingkunngan perairan tambak garam garam di dapati kondsi yang baik hingga tercemar ringan. Di dukung juga dengan persepsi dengan pernyataan " perairan tambak garam di dusun ageng jauh dari pencemaran "sebanyak 12\% sangat setuju, 54\% setuju dan 34\% kurang setuju atau dapat diartikan tempat perairan tambak garam di dusun ageng dekat dengan pencemaran akibat pembuangan sampah ke daera dekat parairan oleh masyarakat sekitar dan untuk pernyataan tentang pengelolahan perairan tambak garam di dusun ageng didapati nilai rata-rata tinggi dengan sebanyak $8 \%$ sangat stuju, $70 \%$ setuju dan $22 \%$ kurang setuju, dari hasil wawancara tentang pengelolahan perairan tambak garam di dusun ageng mneyatkan " dari pengelolahan perairan sudah terbilang baik akan tetati terkendala dari aktivitas masyarakan yang mebuang sampah rumah tanga ke perairan tambak garam. Menurut Lauconsina, mengatak secara prinsip pesisir berfungsi sebagai tempat penerima limbah [3] dan Human mengatakan bahwa masyarakat pesisir memiliki paradigma pesisir sebagai tempat pembuangan sampah [2]. Untuk persepsi tentang konsep pemahaman " sungai bukan tempat pembuangan sampah" memilki nilai rata-rata sangat setuju dengan $74 \%$ sangat setuju dan $26 \%$ setuju. Dari hasil persepsi inimenyebutkan masyarakat mengerti akan konsep lingkungan yang bersih dan sehat akan tetapi masyarakan kurang sadar akan pentingnya menjaga lingkungan bersih dan sehat, dari hasil wawancara kepala desa pinggir papas mengatakan " Tidak dapat di pungkiri bahwa kondisi lingkungan di dusun Ageng desa pinggir papas saat ini perlu upaya yang sangaat serius untuk kondisi lingkungan yang lebih bersih dan sehat, tinggal kesadaran masyarakat di dusun ageng yang harus di perbaiki”.

\section{Kesimpulan}

Kondisi awal perairan tambak garam di dusun Ageng desa Pinggir Papas dapat di simpulkan bahawa perairan tambak garam tergolong kondisi baik hingga tercemar ringan, Kondisi perairan yang termasuk dalam kategori normal dalam baku butu air laut.

Hasil persepsi masyarakat terhadap kondisi lingkungan perairan tambak garam di dusun Ageng desa Pinggir Papas di hasilkan nilai persepsi yang tinggi, akan tetapi hal ini masih berbanding terbalik dengan hasil survey yang mengatakan masyarakakat di dusun Ageng masih kurang kesadaran akan pentingnya menjaga lingkungan dan tidak dapat dipungkiri hal ini mengakibatkan kondisi lingkungan yang perlu perhatian lebih, dalam menerapkan lingkungan bersih dan sehat.

\section{Daftar Pustaka}

[1] Fansuri.S. 2015. Ekplorasi Model Sanitasi Komunal bagi Masyarakat Pedesaan Desa Pinggir Papas, Jurnal "MITSU" Media Informasi Teknik Sipil UNIJA Volume 3, No. 1.:1-3. URL: https://www.ejournalwiraraja.com/index.php/FT/article/view/143/113 
e-Jurnal Ilmiah BIOSAINTROPIS (BIOSCIENCE-TROPIC)

Volume 6/ No.: 1 / Halaman 72 - 81 / Agustus Tahun 2020

ISSN: 2460-9455 (e) - 2338-2805(p)

[2] Humana.B, Rosye.H.R, Suwito.H.K, Maury, Alianto. 2018. Kajian Kualita Air Laut dan Indeks Pencemaran Berdasarkan Parameter Fisika-Kimia di Perairan Distrik Depapre Jayapura. Jurnal Ilmu Lingkungan, Vol:16 No.1: 35-43.

[3] Latuconsina.H. 2020. Ekologi Perairan Tropis Prinsip Dasar Sumber Daya Hayati. Edisi ke-3, UGM press. Yogyakarta.

[4] Rosa, E. 2019, Pemberdayaan Masyarakat dalam Pengelolaan Sampah Rumah Tangga di Tambak Garam Desa Campurejo Kecamatan Panceng Kabupaten Gresik. Skripsi. Program studi pengembangan masyarakat Islam fakultas dakwah dan komunikasi Universitas Islam Negeri Sunan Ampel Surabaya. Surabaya.

[5] Yaqin, S., Saimul, L., Ahmad, S. 2019. Persepsi Masyarakat terhadap Sanitasi Pasar Tradisional (Pasar Blimbing dan Pasar Mergan) di Kota Malang. e-Jurnal Ilmiah BIOSAINTROPIS (BIOSCIENCE-TROPIC) Volume 4 (Edisi Khusus):21-25. https://doi.org/10.33474/e-jbst.v4i3.220.

[6] Syauqi, A., Zaenal, K., Kliwon, H. 2013. Pengelolaan Material Organik Alami Sampah Padat Rumah Tangga Perkotaan dan Persepsi Sosial. URL: https://www.researchgate.net/publication/312589171_Pengelolaan_Material_Orga nik_Alami_Sampah_Padat_Rumah_Tangga_Perkotaan_dan_Persepsi_Sosial_Man agement_of_Natural_Organic Materials_of_Household_MSW and_Social_Percep tion

[7] Arikunto.S, 2006, Metode Penelitian kuantitatif, Bumi Aksara. Jakarta.

[8] Nuraini.E, Fauziah, T. Dan Lestari F. 2019. Penentuan Nilai BOD dan COD Limbah Cair Inlet Laboratorium Pengujian Fisis Politeknik ATK Yogyakarta. Integrated Lab Journal. VOL.07,No.02:10-15 URL: http://ejournal.uin-suka.ac.id/pusat/integratedlab/article/ download/1965/1546

[9] Tahir. A, P.Taba, M.F.Samawil, S.Werorilangi. 2019. Microplastics in water, sediment and salts from traditional salt producing ponds. Global J. Environ. Sci. Manage. 5(4): 431-440

[10] Syauqi.A. 2017. Mikrobiologi Lingkungan Peranan Mikroorganisme Dalam Kehidupan, AndiUNISMA. Yogyakarta

[11] Patty.S.I, Marenda.P.Z, Husen.R, Nebuchadnezzar.A. 2019. Kajian Kualitas Air dan Indeks Pencemaran Perairan Laut di Teluk Manado Ditinjau Dari Parameter Fisika-Kimia Air Laut. JURNAL ILMU KELAUTAN KEPULAUAN, 2 (2) ; 1-13.

[12] Fitriya.Y, Sulardiono, B., and Widyorini, N. 2016. Stuktur Komunitas Diatom Di Perairan Tandon Air Untuk Tambak Garam Di Desa Kedung Mutih Kecamatan Wedung: Demak. Management of Aquatic Resources Journal (MAQUARES), Vol.5, No. 2: 11-16. URL: https://ejournal3.undip.ac.id/index.php/maquares/article/view/11641

[13] Putra, A. dan Semeidi.H. 2017. Kualitas Perairan Pasca Cemaran Sampah Di Pantai Kuta Bali. Jurnal Ilmu dan Teknologi Kelautan Tropis, Vol.9, No. 1:57-66. URL https://www.researchgate.net/publication/322226468_Kualitas_Perairan_Pasca_Cemaran_ Sampah Laut di Pantai Kuta Bali

[14] Irwan.F, Afdal. 2016. Analisis Hubungan Konduktivitas Listrik deangan Total Dissolved solid (TDS) dan Temperatur pada beberapa jenis air. Jurnal Fisika Unad, Vol.5,No.1: URL:http://jfu.fmipa.unand.ac.id/index.php/jfu/article/download/192/172

[15] Wibawa.G.N, Luthfi.O.M. 2017. Water Quality of Coral Reef Ecosystem at Sempu Strait, Sendang Biru Malang, J. Segara Vol.13 No.1: 25-35 
e-Jurnal Ilmiah BIOSAINTROPIS (BIOSCIENCE-TROPIC)

Volume 6/ No.: 1 / Halaman 72 - 81 / Agustus Tahun 2020

ISSN: 2460-9455 (e) - 2338-2805(p)

[16] Tamyiz.M. 2015. Perbandingan Rasio BOD/COD pada Area Tambak di Hulu dan Hilir Terhadap Biodegradabilitas Bahan Organik, Journal of Research and Technology, Vol. 1No. 1:9-15. URL: https://core.ac.uk/download/pdf/228914678.pdf

[17] Supriyantini, 2017, Studi Kandungan Bahan Organik Pada Beberapa Muara Sungai di Kawasan Ekosistem Mangrovedi wilayah Pesisir Pantai Utara Kota Semarang. Buletein Oseoanografi Marina.

[18] Joesidawati.M.I, 2018, Pencemaran Mikroplartik di sepanjang Pantai Kabupaten Tuban, SNasPPM, ISSN:2580-3913; online ISSN:2580-3921.

[19] Victori.A.V, 2017, Kontaminan Mikroplastik di Perairan Tawar, REsearchgase.net.

[20] Sutiknowati, L.I. 2018. Keragaman Bakteri pada Perairan Sabang. Provinsi Aceh. A Scientific Journal, Vol.35, No.2:54-62. DOI: 10.20884/1.mib.2018.35.2.523

[21] Bird.P, Benjamin.B, Nicole.K, Erin.C, James.A. 2020. Evaluation of The 3M Petrifilm rapid E.coli/ Coliform: Collaborative Study. Journal of AOAC International, 10(2):2018.13

[22] Sunarti. R.N. 2015. Uji Kualitas Air Sumur Dengan Menggunkan Metode MPN (Most Proble Numbers). Bioilmi, Vol.1, No.1:30-34 URL: http://jurnal.radenfatah.ac.id/index.php/ bioilmi/article/download/1128/946/

[23] Desahariyanto.D, Subaidilla.F, Diana, A.I.N. 2016. Strategi Pengelolaan Sampah di Desa Pinggir Papas Kabupaten Sumenep. Jurnal "MITSU" Media Informasi Teknik Sipil UNIJA Volume 4, No. 1:1-3. URL: https://www.ejournalwiraraja.com/index.php/FT/article/view/208/173 